\title{
Isolation, Screening and Molecular Identification of Cellulose-degrading Bacteria from Paper and Pulp Mill Dumpsites
}

\author{
Temitayo Omotunde Olowomofe ${ }^{1}$, Toyin Funmilola Babalola ${ }^{2}$, Oluwabusayo Odunola Oluyide ${ }^{3}$, \\ Aderonke Adeyanju ${ }^{1}$ \\ ${ }^{1}$ Department of Microbiology, Faculty of Science, Ekiti State University, Ado-Ekiti, Nigeria \\ ${ }^{2}$ Department of Environmental Health Sciences, College of Health Science and Technology, Ijero-Ekiti, Nigeria \\ ${ }^{3}$ Department of Biomedical Engineering, College of Health Science and Technology, Ijero-Ekiti, Nigeria
}

Email address:

motunde21@yahoo.com (T. O. Olowomofe), temitayo.olowomofe@eksu.edu.ng (T. O. Olowomofe)

To cite this article:

Temitayo Omotunde Olowomofe, Toyin Funmilola Babalola, Oluwabusayo Odunola Oluyide, Aderonke Adeyanju. Isolation, Screening and Molecular Identification of Cellulose-degrading Bacteria from Paper and Pulp Mill Dumpsites. Frontiers in Environmental Microbiology. Vol. 5, No. 3, 2019, pp. 77-83. doi: 10.11648/j.fem.20190503.12

Received: July 6, 2019; Accepted: August 26, 2019; Published: September 20, 2019

\begin{abstract}
This study evaluates cellulose degrading bacteria isolates from paper mill dumpsites and their cellulolytic activity. Forty-one cellulose-degrading bacteria (CDB) were isolated from soil samples from seven different paper and pulp mill dump sites using enrichment method. The isolates were identified based on Morphology and Biochemical characterization while the identities of the potent cellulolytic bacteria isolates were confirmed by 16SrRNA sequencing. The optimum $\mathrm{pH}$, temperature and incubation period for cellulose production by the CBD were determined. Isolates EFB3, ADB4, EFB1 and EFB4 exhibited the maximum zone of clearance around the colony with diameter of $50 \mathrm{~mm}, 43 \mathrm{~mm}, 44 \mathrm{~mm}$ and $54 \mathrm{~mm}$ and with the hydrolytic value of 10, 10.6, 8.8 and 7.6 respectively. The three selected bacteria with highest cellulose-degrading ability had $96 \%$ similarity with Enterobacter soli, Eubacterium ventriosum and Klebsiella michiganensis. Production of cellulase by the bacteria were influenced by environmental factors. Klebsiella michiganensis had optimum activity $(38.5 \mathrm{U} / \mathrm{ml} / \mathrm{min})$ after 72 hours while Enterobacter soli and Eubacterium ventriosum had optimum cellulase activity of $35.5 \mathrm{U} / \mathrm{ml} / \mathrm{min}$ and $32.2 \mathrm{U} / \mathrm{ml} / \mathrm{min}$ respectively after 48 hours. Enterobacter soli, Klebsiella michiganensis and Eubacterium ventriosum had optimum cellulase activity of $38 \mathrm{U} / \mathrm{ml} / \mathrm{min}, 35.6 \mathrm{U} / \mathrm{ml} / \mathrm{min}$ and $35.2 \mathrm{U} / \mathrm{ml} / \mathrm{min}$ respectively at $\mathrm{pH} 7$ while they recorded lower cellulase activity at acidic and alkaline $\mathrm{pH}$ ranges. Eubacterium ventriosum and Klebsiella michiganensis exhibited optimum activity of 25.12 $\mathrm{U} / \mathrm{ml} / \mathrm{min}$ and $20.55 \mathrm{U} / \mathrm{ml} / \mathrm{min}$ respectively at $40^{\circ} \mathrm{C}$. Enterobacter soli had the least cellulase activity with its optimum $(15.02 \mathrm{U} / \mathrm{ml} / \mathrm{min})$ at $35^{\circ} \mathrm{C}$. The findings of this study revealed the abundance of bacteria equipped with the essential enzymatic capability to decompose cellulosic materials in the study area. These bacteria can also be used for mass production of cellulase.
\end{abstract}

Keywords: Cellulose, Congo-Red Agar, Cellulolytic Activity, Cellulose-degrading Bacteria (CDB)

\section{Introduction}

Waste management is a major concern in all pulp and paper mills. On the average, $35 \%$ of the materials entering pulp and paper factories progresses toward becoming build up in types of rejects [1]. These wastes are rich in lignicellulosic materials mainly composed of cellulose and lignin with a small ratio of hemicelluloses [2]. However, several methods have been employed to dispose of the wastes pulp and paper production generates. Currently, the residue from pulp and paper mills is handled by the waste handling components of the mill and is discharged to the air in the form of stack gases, to the water in the form of treated effluent, and to the land in the form of solid waste and sludge [3]. Incineration, appears as the most common disposal method since it decreases the volume of material that needs to be landfilled (the ash) and recovers some energy from the sludge, thus reducing the need for other fuels. This method is faced with drawbacks of the emission of poisonous gases into the environment. Microorganisms play important role in the 
conversion of lignocellulose wastes into valuable products like biofuels produced by fermentation [3]. This is achieved with the help of cellulolytic system where cellulose can be converted to glucose in a much cheaper and biologically favourable process [4]. Cellulase enzymes, which can hydrolyze cellulose forming glucose and other commodity chemicals, can be divided into three types: endoglucanase (endo-1, 4- $\beta$-D-glucanase); cellobiohydrolase or exoglucanase (exo-1, 4- $\beta$-D-glucanase) and $\beta$-glucosidase $(1,4-\beta$-D-glucosidase) $[5,6]$.

Many microorganisms have been reported with cellulosic activities including many bacterial and fungal strains both aerobic and anaerobic. Chaetomium, Fusarium Myrothecium, Trichoderma. Penicillium, Aspergillus, and so forth, are some of the reported fungal species responsible for cellulosic biomass hydrolysation. Cellulolytic bacterial species include Trichonympha, Clostridium, Actinomycetes, Bacteroides succinogenes, Butyrivibrio fibrisolvens, Ruminococcus albus, and Methanobrevibacter ruminantium [7, 8]. The study focuses on the isolation and molecular identification of cellulose-degrading bacteria from soil of paper waste disposal sites and evaluation of their cellulolytic activity.

\section{Materials and Methods}

\subsection{Samples Collection}

Soil samples were collected from seven different paper mill dump sites in Ado-Ekiti. The samples were collected into sterile bottles and transported to the laboratory for further analyses.

\subsubsection{Isolation of Cellulose-Degrading Bacteria}

One gram of each sample was introduced into cellulose agar containing (g/l): $\mathrm{NaNO}_{3} 2.5 \mathrm{~g} ; \mathrm{KH}_{2} \mathrm{PO}_{4} 2 \mathrm{~g} ; \mathrm{MgSO}_{4} 0.2 \mathrm{~g}$; $\mathrm{NaCl} 0.2 \mathrm{~g} ; \mathrm{CaCl} .6 \mathrm{H}_{2} \mathrm{O} \quad 0.1 \mathrm{~g}$; cellulose $2.0 \mathrm{~g}$. Cellulosedegrading bacteria were isolated using serial dilutions and spread plate technique. The total cellulose- degrading bacteria in colony forming units $/ \mathrm{ml}$ (CFU/ml) were calculated by multiplying from colonies counted on plates by the corresponding dilution factor. Pure isolates were obtained using streaking method, the isolates were stored in agar slants as stock cultures and preserved at $4{ }^{\circ} \mathrm{C}$ for further characterization, identification and cellulase enzymes production.

\subsubsection{Screening of Cellulose-Degrading Bacteria}

Confirmation of cellulose-degrading ability of bacterial isolates was performed by streaking on the cellulose Congo Red agar media with the following composition: $\mathrm{KH}_{2} \mathrm{PO}_{4} 0.5 \mathrm{~g}, \mathrm{MgSO}_{4} 0.25 \mathrm{~g}$, cellulose $2.0 \mathrm{~g}$, agar $15 \mathrm{~g}$, Congo-Red $0.2 \mathrm{~g}$, and gelatin $2.0 \mathrm{~g}$; distilled water 1litre at $\mathrm{pH} 6.8-7.2$. The use of Congo-Red as an indicator for cellulose degradation in an agar medium provides the basis for a rapid and sensitive screening test for cellulolytic bacteria. Colonies showing discoloration of Congo-Red were taken as positive cellulose-degrading bacterial colonies and only these were taken for further study. Cellulose-degrading potential of the positive isolates was also qualitatively estimated by calculating hydrolysis capacity $(\mathrm{HC})$, that is, the ratio of diameter of clearing zone and colony [9].

\subsection{Identification of Cellulose-Degrading Bacteria}

The isolates were classified on the basis of biochemical, physiological and morphological characteristics according to Bergey's manual of determinative bacteriology [10].

Molecular Characterization of Selected Bacterial Isolates

DNA of the selected isolates were extracted using the Jena Bioscience Bacteria DNA Preparation Kit. Preceding to sequencing, the DNA was amplified using the polymerase chain reaction (PCR) technique in which two universal primers were used for amplification: Forward primer: 27F(AGAGTTTGATCCTGGCTCAG). Reverse primer: 1492R(GGTTACCTTGTTACGACTT). PCR products were purified and sequenced using a PCR purification kit. The purified PCR products were reconfirmed by gel electrophoreses with $1 \%$ agarose gel. All PCR products were sent to inquaba biotech (South Africa) for Sanger sequencing. Sequences were further analyzed using BLAST from the National Center of Biotechnology Information (NCBI) website.

\subsection{Enzyme Production}

The selected cellulose-degrading bacterial isolates were cultured in enzyme production medium containing $(\mathrm{g} / \mathrm{l})$ : CMC 10.0, peptone 10.0, $\mathrm{MgSO}_{4} .7 \mathrm{H}_{2} \mathrm{O} 0.3, \mathrm{~K}_{2} \mathrm{HPO}_{4} 2.0$, $\left(\mathrm{NH}_{4}\right)_{2} \mathrm{SO}_{4} 2.5$, and gelatin 2.0. The $\mathrm{pH}$ was adjusted at 6.87.2. The medium was incubated at $37^{\circ} \mathrm{C}$ for 72 hours [11]. After $72 \mathrm{~h}$ incubation, inoculated broth was subjected to centrifugation at $5000 \mathrm{rpm}$ for $20 \mathrm{~min}$ at $4^{\circ} \mathrm{C}$. Supernatant was collected and preserved as a crude enzyme for further enzymes assay.

\subsubsection{Enzyme Assay}

The carboxymethylcellulase (CMCase) activity was estimated as described by Behera et al. [12]. One per cent (1\%) solution of carboxymethyl cellulose (CMC) in $0.05 \mathrm{M}$ citrate buffer $(\mathrm{pH} 4.8)$ was used as substrate. The reaction mixture contained $0.5 \mathrm{ml}$ of substrate solution and $0.5 \mathrm{ml}$ of properly diluted enzyme solution. The reaction was carried out at $50^{\circ} \mathrm{C}$ for 30 minutes and the reaction was stopped by adding $3 \mathrm{ml}$ of DNS solution to the reaction mixture. The reaction mixture was then boiled at $100^{\circ} \mathrm{C}$ for 5 minute. One unit of CMCase activity was expressed as $1 \mu \mathrm{mol}$ of glucose liberated per $\mathrm{ml}$ of enzyme per minute, using glucose as a standard.

\subsubsection{Effect of Time-course on Cellulase Production}

Inoculated cellulase production medium were incubated at different times $(24 \mathrm{~h}, 48 \mathrm{~h}, 72 \mathrm{~h}$ and $96 \mathrm{~h})$ at $37^{\circ} \mathrm{C}$ and $\mathrm{pH}$ 7.0. CMCase activity was measured at each time interval. 


\subsubsection{Effect of $\mathrm{pH}$ on Cellulase Production}

The cellulose production medium was subjected to different initial $\mathrm{pH}(3.0,5.0,7.0,9.0,11.0)$ at $37^{\circ} \mathrm{C}$ for $48 \mathrm{~h}$. CMCase activity was measured after incubation.

\subsubsection{Effect of Temperature on Cellulase Production}

$\mathrm{CMCase}$ activity of inoculated broth incubated at different temperatures $\left(30^{\circ} \mathrm{C}, 35^{\circ} \mathrm{C}, 40^{\circ} \mathrm{C}, 45^{\circ} \mathrm{C}, 50^{\circ} \mathrm{C}, 55^{\circ} \mathrm{C}, 60^{\circ} \mathrm{C}\right)$ was determined after $48 \mathrm{~h}$.

\subsection{Statistical Analysis}

Data generated were analyzed with Excel 2016 ANOVA

\section{Results and Discussion}

Cellulolytic microorganisms such as fungi and bacteria are responsible for much of the cellulose degradation in soils. Their cellulose-degrading abilities have been linked to the production of cellulase enzyme. In this study, soil samples collected from paper and pulp mill dumpsites were analyzed for cellulolytic bacteria. Considerably high cellulosedegrading bacteria were isolated from the different dumpsites (Table 1). Although analysis of variance revealed that there was no significant difference $(\mathrm{p}<0.05)$ in $\mathrm{CDB}$ counts in the different sample collection sites.

Table 1. Cellulose-degrading bacteria (CDB) Count from Paper and Pulp Mill Dumpsites.

\begin{tabular}{ll}
\hline Soil Samples & Total CDB $\left(\log _{10} \mathbf{C F U} / \mathbf{m l}\right)$ \\
\hline DP1 & $6.25 \pm 0.02$ \\
DP2 & $8.30 \pm 0.04$ \\
DP3 & $7.85 \pm 0.01$ \\
DP4 & $5.22 \pm 0.01$ \\
DP5 & $8.18 \pm 0.02$ \\
DP6 & $5.89 \pm 0.03$ \\
DP7 & $7.28 \pm 0.02$ \\
\hline
\end{tabular}

*Values are the mean and standard errors of two replicates

Forty-one cellulose-degrading bacteria (CDB) which belonged to genera Pseudomonas, Bacillus, Enterobacter, Klebsiella and Proteus were isolated from soil samples collected from the paper and pulp mill dumpsites. Similar findings of Tabo and Monsalud [13] have also reported the occurrence of Bacillus cereus in dumpsites. Thatoi et al [14] also reported the cellulolytic activity of Pseudomonas spp, Bacillus spp isolated from mangrove soil of Bhitarakanika, Odisha.

The isolates were further screened on a Congo-red agar for 72 hours. Clear zone and discoloration on Congo-red agar indicated the cellulose degrading abilities of the isolates (EFB 4, ADB 4, EFB 3, EFB 1). Qualitative Cellulosedegrading ability estimated by calculating hydrolysis capacity (HC) showed that Isolates EFB 4, ADB 4, EFB 3 and EFB 1 showed maximum clear zone of $44 \mathrm{~mm}, 50 \mathrm{~mm}$, $54 \mathrm{~mm}$ and $43 \mathrm{~mm}$ respectively with hydrolytic capacity value of 8.8, 10.0, 7.6 and 10.6 respectively (Table 2). The range of $\mathrm{HC}$ value obtained is similar to range reported by Lu et al.
[15], whereas Hatami et al [16] found the hydrolytic value between 1.38 to 2.33 and 0.15 to 1.37 of cellulolytic aerobic bacterial isolates from farming and forest soil, respectively. The difference could be due to the location of the soil sample used for this research work which is paper mill dumpsite with high tendency of cellulose degrading bacteria, since the dump site is majorly filled with cellulosic material.

Plate 1 and 2 shows the zone of clearance on cellulose Congo Red agar plates for isolate EFB4 and ADB 4 respectively after 72 hours of incubation. Plate 3 shows the PCR amplification of cellulose degrading bacteria using universal primer (primer pair 27F- 5'AGAGTTTGATCCTGGCT CAG -3', and 1492R 5'GGTTACCTTGTTACGACTT -3'). The PCR amplification of the genomic DNA of the cellulose degrading bacteria gave rise to $1500 \mathrm{bp}$ amplicon for the three bacteria isolates: Enterobacter soli, Eubacterium ventriosum and Klebsiella michiganensis.

Table 2. Plates screening of bacteria isolates for cellulose degradation.

\begin{tabular}{lllll}
\hline Isolates' codes & Isolates & Mean clearing zone $(\mathbf{m m})$ & Mean colony diameter $(\mathbf{m m})$ & Average HC value (mm) \\
\hline & Bacillus sp. & 28 & 5.2 & 5.4 \\
DDP1 & Proteus vulgaris & 30 & 7.2 & 4.1 \\
EFB 1 & Bacillus sp & 38 & 6.4 & 5.3 \\
BDP2 & Pseudomonas sp. & 22 & 4.2 & 5.2 \\
EFB 3 & Klebsiella sp. & 50 & 5.0 & 10.0 \\
FDB3 & Enterobacter sp. & 44 & 4.5 & 9.7 \\
EFB 4 & Pseudomonas sp. & 54 & 7.0 & 7.6 \\
ADB 4 & Enterobacter sp. & 43 & 4.1 & 10.6 \\
ADB2 & Bacillus sp & 25 & 6.2 & 4.0 \\
BDP3 & Enterobacter sp. & 35 & 5.8 & 6.0 \\
\hline
\end{tabular}




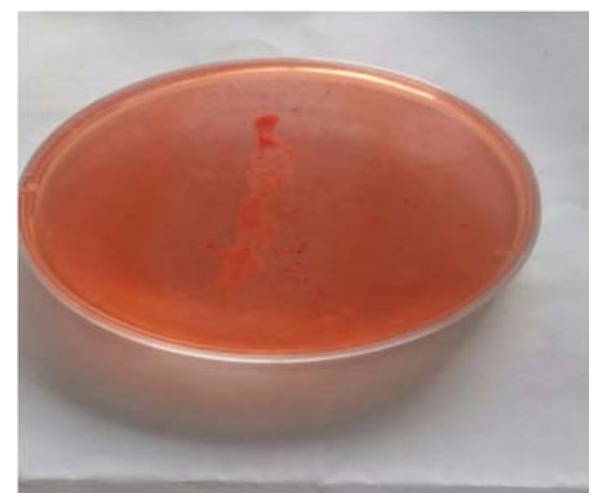

Figure 1. Zone of clearance on cellulose Congo Red agar plates for isolate EFB 4 after 72 hours of incubation.

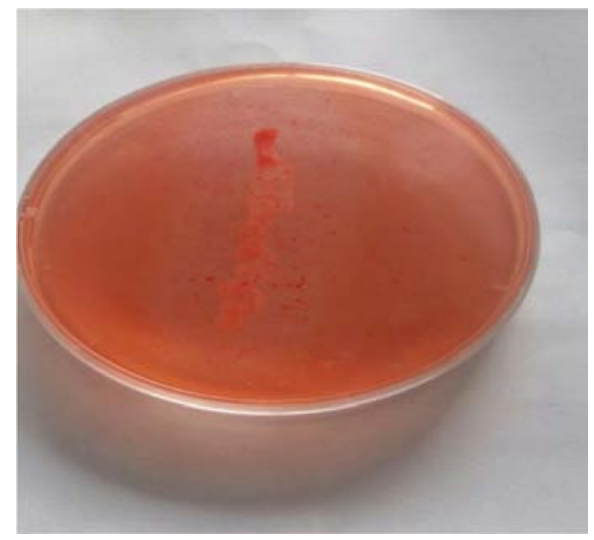

Figure 2. Zone of clearance on cellulose Congo Red agar plates for isolate $A D B 4$ after 72 hours of incubation.

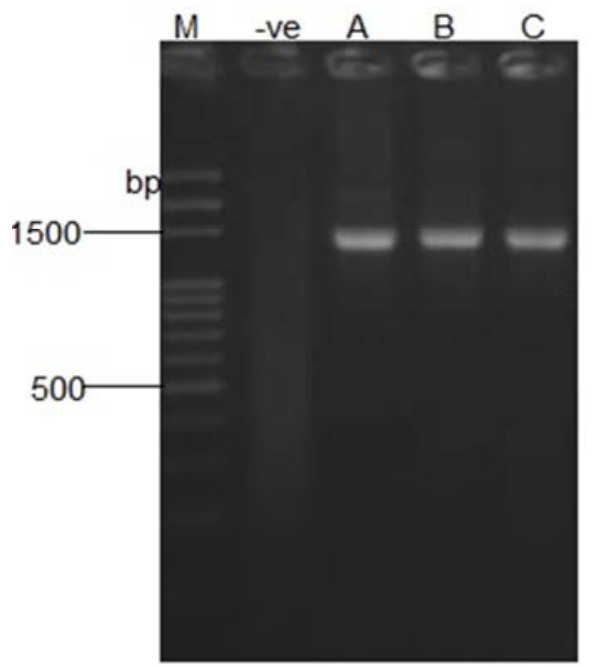

Figure 3. PCR amplification of DNA of cellulose degrading bacteria isolated from paper mill dump sites.

Key:

M: Molecular marker -ve: Negative control

A-Enterobacter soli

B-Eubacterium ventriosum

C-Klebsiella michiganensis
Molecular Characterization of the selected cellulosedegrading bacteria

The three selected isolates EFB 4, ADB 4 and EFB1 DNA submitted to the NCBI database had $96 \%$ similarities with Enterobacter soli strain LF7, Eubacterium ventriosum strain ATCC 27560 and Klebsiella michiganensis strain W14. They were assigned accession numbers NR_117547.1, |NR_118670.1 and NR_118335.1 respectively.

Table 3. Taxonomic affiliation and \% Sequence similarities of Bacteria Isolates with closest relatives from the Genbank database.

\begin{tabular}{llll}
\hline Isolates' Codes & Identity & (\%) Similarity & Accession no \\
\hline EFB 4 & $\begin{array}{l}\text { Enterobacter soli } \\
\text { Eubacterium } \\
\text { ventriosum }\end{array}$ & 96 & 117547.1 \\
EFB1 & $\begin{array}{l}\text { Klebsiella } \\
\text { michiganensis }\end{array}$ & 96 & 118670.1 \\
\hline
\end{tabular}

ISOLATE EFB4

Enterobacter soli strain LF7 16S ribosomal RNA gene, partial sequence

Sequence ID: gi|645320312|NR_117547.1

Length: 1535 Number of Matches: 1

Related Information

Range 1: 3 to 25 GenBankGraphics Next Match Previous Match

Alignment statistics for match \#1

$\begin{array}{lllll}\text { Score } & \text { Expect } & \text { Identities } & \text { Gaps } & \text { Strand } \\ 37.4 \text { bits(40) } & 0.095 & 22 / 23(96 \%) & 0 / 23(0 \%) & \text { Plus/Plus }\end{array}$

\section{Query 14 GAGAGTTAGATCCTGGCTCAGAT 36}

||||||| |||||||||||||||

Sbjct 3 GAGAGTTTGATCCTGGCTCAGAT 25

TCCGGTAGTACACGAGAGTTAGATCCTGGCTCAG

ATATTCAACGGGCACCCCATTTTTT

TGCCCCGGCCAAAAAAAATCCAAAAGGGGGAAC CCCATTTTTTTTTCCCCCCCCCAAAA

AAAATCCCAAAGGGCACCCCCCTTTTTTTTTTTTC

CCGCCCCCACCCTTCGATAACGAAC

CCCCCCGTTTTTTTGCCTCCCCGCCAAATAGTGGG

CGGGGGGGCAAAAAGGTTTTTTTTT

TCCTTTGGCACAGCAAGCCGCGAGGGAAGGCATGA

TAGTTTTTTTTTTCTCACGACCCAA

GGGGGCGGGGGGGGTCCCTGTTTTTTTTTTCTTGT

TACAAAAAAAAGGAGGGGGGAGGAA

AGCGTTTTTTTTTTTTACTTTAACTTGAGACAGAG

GGGCCCATAAAAATGTTTTCTTTCT

TCTGAAAAGGAAAGATATTAAGGGGCAGACAGTG

GTGTTTTCTTATACTGCAACAGCGGC

GCCCGGGGGACCGGACCTTTGATTTTTTCAGGCAC

AAACTGGGAGACGGGGGGGTGGCCG

ATGCTGCCAAGATGGAGCGGCACAAGTAACGGTG

GGACCAATCCTTGTCTGATTTTCGTC

CACACGAAGCCCGGGGAGCGG

ISOLATE ADB4

Eubacterium ventriosum strain ATCC 27560 16S

ribosomal RNA gene, partial sequence 
Sequence ID: gi|645321785|NR_118670.1

Length: 1481Number of Matches: 1

Related Information

Range 1: 5 to 27 GenBankGraphics Next Match Previous Match

\begin{tabular}{lllll}
\multicolumn{2}{l}{ Alignment statistics for match \#1 } & & \\
Score & Expect & Identities & Gaps & Strand \\
37.4 bits(40) & 0.095 & $22 / 23(96 \%)$ & $0 / 23(0 \%)$ & Plus/Plus
\end{tabular}

Query 12 ACGAGAGTTAGATCCTGGCTCAG 34 ||||||||| |||||||||||||

Sbjct 5 ACGAGAGTTTGATCCTGGCTCAG 27

CTTTAACGAGAGTTTGATCCTGGCTCAGGATGAA

CGCTGGCGGCGTGCTTAATACATGCA

GTCGAACGAAGCACCTTGGACAGAATCCTTCGGG

AGGAAGACCATTGTGACTGAGTGGCG

GACGGGTGAGTAACGCGTGGGTAACCTGCCTTGT

ACAGGGGGATAACAGTTGGAAACGAC

TGCTAATACCGCATAAGCGCACAGTACCGCATGG

TACGGTGTGAAAAACTCCGGTGGTAC

AAGATGGACCCGCGTCTGATTAGCTGGTTGGTGA

GGTAACGGCCCACCAAGGCGACGATC

AGTAGCCGACTTGAGAGAGTGATCGGCCACATTG

GGACTGAGACACGGCCNNAACTCCTA

CGGGAGGCAGCAGTAGGGAATATTGCACAATGGG

GGAAACCCTGATGCAGCGACGCCGCG

TGAAGGAAGAAGTATTTCGGTATGTAAACTTCTA

TCAGCAAGGAAGAAAATGACGGTACT

TGACTAAGAAGCCCCGGCTAAATACGTGCCAGCA

GCCGCGGTAATACGTATGGGAGCGTT

ATCCGGATTTACTGGGTGTAAAGGGAGCGTAGGC

GGCATGGCAAGTCAGAAGTGAAAGCC

TGGGNCTCAACCCCGGAATTGCTTTTGAAACTGTC

AGGCTAGAGTGTCGGAGGGGTAAGC

GGAATTCCTAGTGTAGCGGTGAAATGCGTAGATA

TTAGGAGGAACACCGGTGGCGAAGGC

ISOLATE EFB 1

Klebsiella michiganensis strain W14 16S ribosomal RNA gene, partial sequence

Sequence ID: gi|645321348|NR_118335.1

Length: 1395Number of Matches: 1

Related Information

Range 1: 3 to 25GenBankGraphics Next Match Previous Match

Alignment statistics for match \#1

Score Expect Identities Gaps Strand

37.4 bits(40) $\quad 0.095 \quad 22 / 23(96 \%) \quad 0 / 23(0 \%) \quad$ Plus/Plus

Query 14 GAGAGTTAGATCCTGGCTCAGAT 36

||||||| |||||||||||||||

Sbjct 3 GAGAGTTTGATCCTGGCTCAGAT 25

AAACGGGAAGGGTACCGAACCGTATGACCGGCGC

TAAAAGATATGTAACGGCCCCCCCCT

TTTTTTTTGCCCCGGGCAAAAAAAATTAAGAAGG GGGGCCCCCTTTTTTTTTTCCCCCCG

CAAAAAAAAAAAAAAAAGGGCCCCCCCTTTTTTT

TTTCCCCCCCCCCAAAAATCCGCACC
TGCCCCAACCCTAATTTTTTTTTTCGGAACAAACA AAAAGGCGGGGGGGTAACGCATCTT

TTTTTATTTTTTTCAAACCGGACGAGGAGGGGGGG GCCCCCCCTTTTTTTTTTTTACACC

CCCCACACCCCCACGGGGGGGCCATTATGTATTTT

TTCCCATCCCCCCAAACCGGGGGGG

GGCGGGGGATGTTTTTTTTATATGTCCCTAGGCTA

ACAGACACCGTTGGGGGGCAAAAAA

TTTTTTTTGATGACCCCCCTACCAGGGCGGGGCCG

CACAGAAAATTTTCTTTTTATATAC

CCGCACGACGCGGGGGAAGAAAGAAGGGTCATTT

GCCTGTCGGGGATCAACCGCGGGAGA

GGGGCAGTGGGTTTTTTGATACAAGAGAGCAGGA

CTGGGGCTAGGGAGTAATTATCTTTT

GGATCACGCTTAGCGAAGAGAGGGAGAGACGCA

GGATGTACACGCAACGCAAGAGAGACA

ACGAGTAGGACAGAACTTCGTACATAGTAC

Three of the CDB isolates which exhibited the highest cellulose degrading ability were selected for cellulose production. The effect of time-course on cellulase production is shown in Figure 4. Substantial cellulase activity was recorded from all the three isolates at all the incubation periods examined. However, Klebsiella michiganensis had optimum activity $(38.5 \mathrm{U} / \mathrm{ml} / \mathrm{min})$ after 72 hours while Enterobacter soli and Eubacterium ventriosum had optimum cellulase activity of $35.5 \mathrm{U} / \mathrm{ml} / \mathrm{min}$ and $32.2 \mathrm{U} / \mathrm{ml} / \mathrm{min}$ respectively after 48 hours. The three isolates recorded lowest activity after 96 hours.

The effect of growth medium $\mathrm{pH}$ on cellulase production was examined at $\mathrm{pH}$ range 3 to 11 (Figure 5). The bacteria isolates; Enterobacter soli, Klebsiella michiganensis and Eubacterium ventriosum had optimum cellulase activity of $38 \mathrm{U} / \mathrm{ml} / \mathrm{min}, 35.6 \mathrm{U} / \mathrm{ml} / \mathrm{min}$ and $35.2 \mathrm{U} / \mathrm{ml} / \mathrm{min}$ respectively at $\mathrm{pH} 7$ while they recorded lower cellulase activity at acidic and alkaline $\mathrm{pH}$ ranges (Figure 5).

Initial $\mathrm{pH}$ of the medium has been reported to strongly influence many enzymatic processes by affecting the transport of a number of chemical products and enzymes across the cell membrane [17]. Microorganisms differ in their optimum $\mathrm{pH}$ for growth. Differences in interactions of media compositions and microbial specificities are the cause of variation in optimal initial $\mathrm{pH}$ for cellulase production among bacterial groups [18]. Microorganisms have the ability to grow over wide range of $\mathrm{pH}$ [19]. Nevertheless, extreme $\mathrm{pH}$ can damage microorganisms by distracting the plasma membrane as well as inhibiting the enzymatic activity and membrane transport proteins [20].

The effect of temperature on cellulase activity was examined at different temperatures ranging from $25-50^{\circ} \mathrm{C}$. The result revealed that Eubacterium ventriosum exhibited relatively high cellulase activity within the temperature range examined. However, its optimum activity $(25.12 \mathrm{U} / \mathrm{ml} / \mathrm{min})$ was recorded at $40^{\circ} \mathrm{C}$ while the least activity $(15.7 \mathrm{U} / \mathrm{ml} / \mathrm{min})$ was at $55^{\circ} \mathrm{C}$. Klebsiella michiganensis followed the same trend but recorded lower cellulase activity compared to Eubacterium ventriosum. Enterobacter soli had the least cellulase activity with its optimum $(15.02 \mathrm{U} / \mathrm{ml} / \mathrm{min})$ at $35^{\circ} \mathrm{C}$ 
(Figure 6). This suggests that each bacterium has its own optimum temperature for enzyme production. The influence of temperature on enzyme production has been reported by Juturu and $\mathrm{Wu}$ [21]. Incubation temperature is paramount for optimal enzyme production due to alterations in microbial protein structure and properties with temperature variations. At temperatures below or above the optimum, metabolic activities are reduced, with consequent inhibition in growth and enzymes synthesis [22]. Cultivation of bacteria below the environmental temperature where the bacteria was isolated could also negatively influence the growth rate, enzyme activities, alteration of cell composition, and differential nutritional requirements [23].

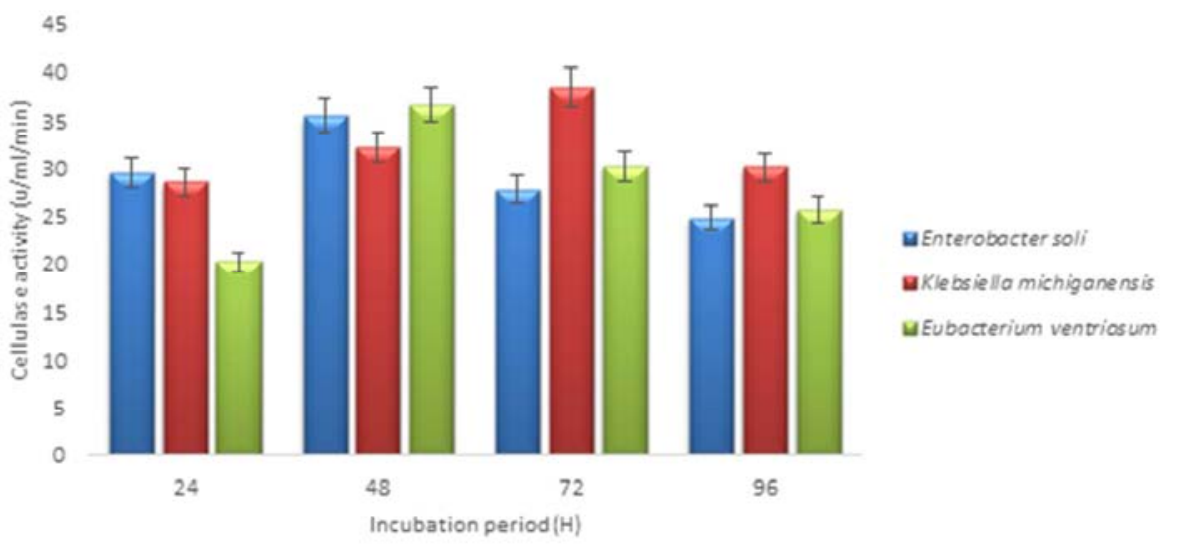

Figure 4. Effect of Time-course on cellulase production.

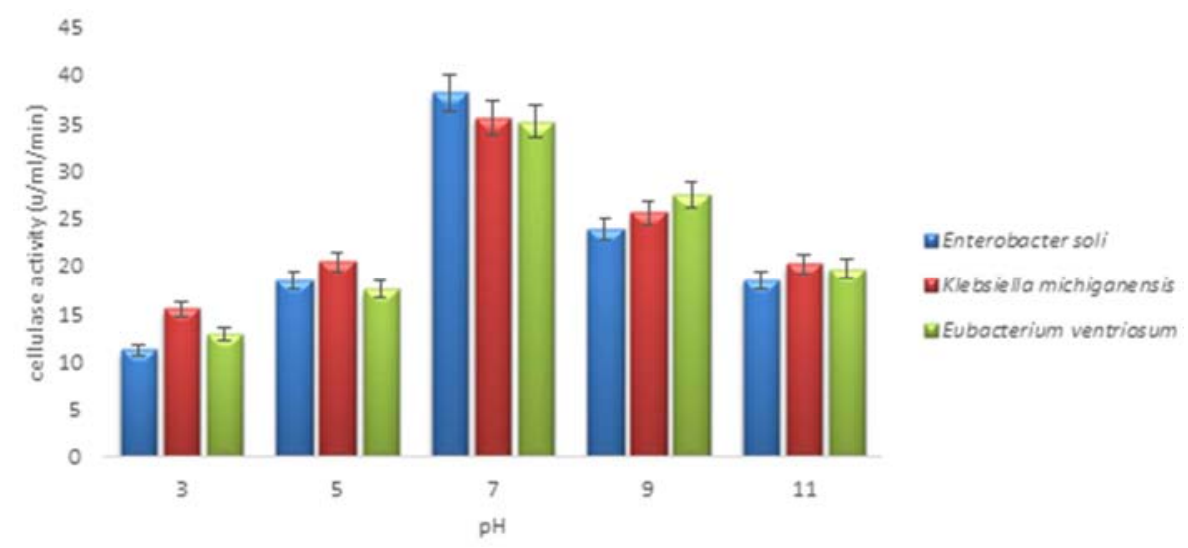

Figure 5. Effect of pH on cellulase production.

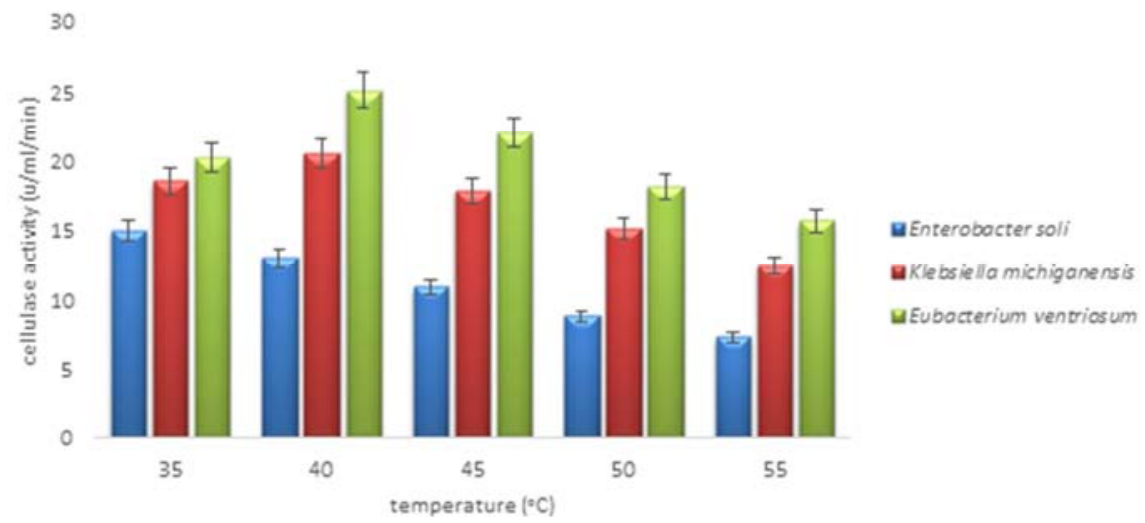

Figure 6. Effect of Temperature on cellulase production.

\section{Conclusion}

The study established that bacteria indigenous to paper and pulp dumpsites are potential tools for cellulose decomposition. Three bacteria with remarkable cellulolytic activity were isolated from paper dumpsites. They were identified as Enterobacter soli, Eubacterium ventriosum and Klebsiella michiganensis based on 16S rDNA gene sequence 
analysis. They also produced substantial amount of cellulase. However, production of this enzyme by these bacteria were influenced by some environmental factors. Therefore, these bacteria can be used in the decomposition of cellulosic and lignocellulosic wastes and mass production of cellulase.

\section{References}

[1] Saranraj, P., Stella, D. and Reetha, D. (2012). Microbial cellulases and its applications: A review. Int. J. Biochem. Biotechnol. Sci. 1: 1-12.

[2] Malherbe, S. and Cloete, T. E. (2003). Lignocellulose biodegradation: fundamentals and applications. Reviews in Environmental Sciences and Biotechnology, 1: 105-114.

[3] Lynd, L. R., Weimer, P. J., Van Zyl, W. H. and Pretorius, I. S. (2002). Microbial Cellulose Utilization: Fundamentals and Biotechnology. American Society for Microbiology, 66 (3): 506-577.

[4] Gupta, P., Samant, K. and Sahu, A. (2012). "Isolation of Cellulose-Degrading Bacteria and Determination of Their Cellulolytic Potential," Int J Microbiol, 2012: 1-5.

[5] Li, Y. H., Ding, M., Wang, J., Xu, G. J. and Zhao, F. (2006). A novel thermoacidophilic endoglucanase, Ba-EGA, from a new cellulose degrading bacterium, Bacillus sp. AC-1. Appl. Microbiol. Biotechnol, 70: 430-436.

[6] Gao, J., Weng, H., Zhu, D., Yuan, M., Guan, F. and Yu, X. (2008). Production and characterization of cellulolytic enzymes from the thermoacidophilic fungal Aspergillus terreus M11 under solid state cultivation of corn stover. Bioresour. Technol., 99: 7623-7629.

[7] Schwarz, W. H. (2001). "The cellulosome and cellulose degradation by anaerobic bacteria," Applied Microbiology and Biotechnology, 56 (5-6): 634-649.

[8] Milala, M. A., Shugaba, A., Gidado, A., Ene, A. C. and Wafar, J. A. (2005). "Studies on the use of agricultural wastes for cellulase enzyme production by A. niger," Journal of Agriculture and Biological Science, 1: 325-328.

[9] Hendrick, C. W., Doyle, J. D. and Hugley, B. (2005). A new solid medium for enumerating cellulose- utilizing bacteria in soil. Applied and Environmental Microbiology, 61 (55): 2016-2019.

[10] Olutiola, P. O., Famurewa, O. and Sonntag, H. S. (2000). An introduction to General Microbiology (A practical Approach); Measurement of microbial growth. 101-111.

[11] Yin, L. J., Lin, H. H. and Xiao, Z. R. (2010). Purification and characterization of a cellulase from Bacillus subtilis YJ1. $J$. Marine Sci. Technol., 18: 466-471.
[12] Behera, B. C., Parida, S., Dutta, S. K and Thatoi, H. N. (2014). Isolation and identification of cellulose degrading bacteria from mangrove soil of Mahanadi River Delta and their cellulase production ability. American J Microbiol Res. 2: 41-46.

[13] Tabao, N. S. C. and Monsalud, R. G. (2010). "Characterization and identification of high cellulose producing bacterial strains from philippine mangroves," Philipine journal of Systemetic Biology, 4: 13-20.

[14] Thatoi, H. N., Behera, B. C., Dangar, T. K. and Mishra, R. R. (2012). "Microbial biodiversity in mangrove soil of Bhitarakanika, Odisha, India," International Journal of Environmental Biology, 2 (2): 5058.

[15] Lu, W. J., Wang, H. T., Yang, S. J., Wang, Z. C. and Nie, Y. F. (2006). Isolation and characterisation of mesophilic cellulose degrading bacteria from flower stalks-vegetable waste cocomposting system. Journal of General Applied Microbiology, 51 (6), 353-360.

[16] Hatami, S., Alikhsni, H. A., Besharati, H., Salehrastin, N., Afrousheh, M. and Jahromi, Z. Y. (2008) "Investigation of aerobic cellulolytic bacteria in some of north forest and farming soils," The American-Eurasian Journal of Agricultural \& Environmental Sciences, 5: 713-716.

[17] Ellaiah P, Srinivasulu B, Adinarayana K. A review on microbial alkaline proteases. J Sci Ind Res. 2002: 61: 690-704.

[18] Heck, J. X, Hertz, P. F, Ayub, M. A. Z. (2002). Cellulase and xylanase production by isolated Amazon Bacillus strains using soya been industrial residue based solid-state cultivation. Braz J Microbiol., 33: 213-218.

[19] Norsalwani, T., Tengku, L. and Norulaini, N. A. N. (2012). Utilization of lignocellulosic wastes as a carbon source for the production of bacterial cellulases under solid state fermentation. Int J Environ Sci Dev., 3: 136-140.

[20] Shuler, M. L, Kargi, F. (1992). Bioprocess engineering: basic concepts, 1st ed. New Jersey: Prentice Hall.

[21] Juturu, V. and Wu, J. C. (2014). Microbial cellulases: Engineering, production and applications. Renew Sustain. Energy Rev. 33: 188-203.

[22] Ray, A. K., Bairagi, A., Ghosh, K. S. And Sen, S. K. (2007). Optimization of fermentation conditions for cellulase production by Bacillus subtilis CY5 and Bacillus circulans TP3 isolated from fish gut. Acta Ichthyol Piscat. 3: 47-53.

[23] Nkohla1, A., Okaiyeto, K., Olaniran, A., Nwodo, U., Mabinya, L. and Okoh, A. (2017). Optimization of growth parameters for cellulase and xylanase production by Bacillus species isolated from decaying biomass. Journal of Biotech Research, 8: 33-47. 